\title{
KERAGAMAN GEN CYTOCHROME B PADA SIDAT (Anguila bicolor) BERDASARKAN RESTRICTION FRAGMENT LENGTH POLYMORPHISM (RFLP)
}

\section{GENETIC DIVERSITY CYTHOCHROME B OF SIDAT (Anguila bicolor) ASSESED BY RESTRICTION FRAGMENT LENGTH POLYMORHISME (RFLP)}

\author{
Lestari Wilujeng, Gunanti Mahasri dan Mufasirin \\ Fakultas Perikanan dan Kelautan Universitas Airlangga \\ Kampus C Mulyorejo - Surabaya, 60115 Telp. 031-5911451
}

\begin{abstract}
This study aims to analyze the genetic character of Anguilla bicolor based on cytochrome b gene as the basis of information in the study of phylogeny and genetic engineering. The research was conducted from May to September 2013 in the Laboratory of Biotechnology Faculty of Science, University of Brawijaya. This study uses a survey with qualitative descriptive analysis in the laboratory. Samples obtained from direct arrests in Tulungagung Popo Beach, Manado, Medan and Cilacap. Study was initiated by DNA isolation using CTAB method and followed by PCR . Primers used were cytb - 1 (5' - TGCTAACGATGCCCTAGTGG - 3 ') and b CYT - 2 (5' - CTAGTCAACCTACT - AATGGG - 3 ') . PCR results were cut using restriction enzymes and Msp 1 Hha1. Data analysis was performed with the aid of NTSYS software program. Genetic character of a sequence of nucleotide bases making up DNA from the cytochrome b gene were obtained on each sample has a degree of similarity around $32-100 \%$.
\end{abstract}

Keywords : Cytochrome b, Anguila bicolor, RFLP-mtDNA

\section{Pendahuluan}

Satu diantara komoditas perikanan yang memiliki nilai ekonomis tinggi dan saat ini sedang dikembangkan adalah ikan sidat (Anguila bicolor). Permintaan akan sidat cukup tinggi baik lokal maupun ekspor, sementara potensi sidat di sebagian perairan Indonesia pada tahun 2000 semakin menurun.

Sampai saat ini seluruh ekspor sidat masih merupakan hasil tangkapan dari alam, yang dikhawatirkan akan mempengaruhi Populasi di alam, karena pengambilan sidat secara terus menerus dalam jumlah besar dapat menyebabkan stok di alam berkurang drastis. Produksi sidat pada tahun 1990 mencapai 41,5 ton dan pada tahun 1996 menurun hingga 29,1 ton (Haryani, 1999).

Upaya untuk memenuhi permintaan akan sidat harus sudah mulai dipenuhi dengan budidaya yang tentu saja diawali dengan penyediaan benih yang berkualitas, cukup dan berkesinambungan.

Karakteristik ikan sidat perlu diteliti terutama secara genetiknya, hal ini diperlukan terutama dalam upaya pembenihan sidat, dengan memahami dan mengetahui inventarisasi dan evaluasi karakteristik genetik sidat dari beberapa populasi, dapat digunakan sebagai informasi awal atau bahan pertimbangan dalam pelaksanaan breeding program. Sistem pewarisan sifat mtDNA dilakukan secara maternal tanpa rekombinasi. Selain itu dalam mtDNA ini terjadi laju mutasi yang tinggi, sehingga mtDNA dapat dimanfaatkan untuk menentukan keragaman genetik antar individu dalam suatu populasi, hubungan evolusi di antara populasi dan rekontruksi migrasi suatu populasi (Toha, 2001).

Keragaman genetik dapat muncul karena adanya mutasi, seleksi alam, pengaruh lingkungan dan perkawinan (Warwick dkk. 1987). Gen yang digunakan untuk mengetahui keragaman pada sidat adalah gen cythocrome $b$. Sekuen gen $c y t b$ yang berasal dari sidat (Anguila bicolor) mempunyai panjang sekuen 15573 pb (NCBI 2013). Adapun tempat asal atau habitat sidat yang digunakan berasal dari Tulungagung, Malang, Medan dan Lampung. Pemilihan empat lokasi pengambilan sidat karena di empat tempat tersebut banyak ditemukan sidat yang khusus spesies Anguila bicolor

\section{Materi dan Metode}

Ikan uji atau sampel yang digunakan dalam penelitian ini adalah ikan sidat (Anguila bicolor) yang diperoleh dari hasil tangkapan nelayan di Perairan Umum Manado, Lampung, Cilacap dan Tulungagung. Jumlah sampel di setiap lokasi yang digunakan untuk uji genetik adalah 3 ekor dengan ukuran panjang sekitar $7-10$ $\mathrm{cm}$ dan berat $8-15$ gram. 
Amplifikasi mtDNA dengan PCR

DNA Mitokondria diamplifikasikan menggunakan primer universal Cytochrome $\mathrm{b}$

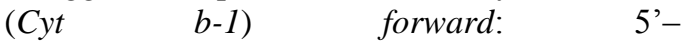
TGCTAACGATGCCCTAGTGG-3' dan $C y t b$ 2: 5'-CTAGTCAACCTACT-AATGGG-3'. (Williams dan Benzie, 1997). Amplifikasi dilakukan menggunakan metode Polymerase Chain Reaction (PCR) dengan komposisi $4 \mu \mathrm{l}$ ddh $2 \mathrm{O}, 2 \mu \mathrm{l}$ primer $\mathrm{F}(30 \mathrm{pmol} / \mu \mathrm{l}), 2 \mu \mathrm{l}$ primer $\mathrm{R}$ (30 pmol/ $\mu \mathrm{l}), 10 \mu \mathrm{l}$ go tag green (promega) dan $2 \mu$ l DNA dimasukkan ke dalam PCR tube. Amplifikasi dilakukan dengan program predenaturasi pada suhu $95^{\circ} \mathrm{C}$ selama 5 menit, denaturasi pada suhu $95^{\circ} \mathrm{C}$ selama 45 detik, annealing pada suhu $62^{\circ} \mathrm{C}$ selama 45 detik dan ekstensi pada suhu $72^{\circ} \mathrm{C}$ selama 45 detik, sebanyak 35 siklus. Lalu ekstensi akhir pada suhu $72^{\circ} \mathrm{C}$ selama 10 menit. Hasil PCR dapat langsung dianalisis dengan elektroforesis atau disimpan di dalam refrigerator.

Gel agarose dibuat dengan cara memanaskan di atas hotplate dan diaduk rata. Setelah gel larut dan berwarna bening, larutan tersebut dibiarkan sampai hangat, kemudian teteskan etidium bromida sebanyak $0,1 \mathrm{ml}$; kemudian dituangkan ke dalam cetakan yang telah terpasang sisir pembuat lubang dengan ketebalan 3-5 mm, selanjutnya gel yang berisi buffer elektroforesis.

Hasil PCR divisualisasikan dengan menggunakan gel agarosa $1.5 \%$. sebanyak 0.45 gram agarosa dilarutkan dalam $30 \mathrm{ml}$ larutan TBE buffer $\mathrm{pH} \sim 8.3$ (45 mM Tris, $45 \mathrm{mM}$ bric acid, $2 \mathrm{mM} \mathrm{Na} 2$ EDTA pH 8.3) dan dididihkan. Setelah mendidih larutan agarosa didinginkan lalu ditambahkan $0.5 \mu \mathrm{l}$ ethidium bromide dan dituang dalam cetakan gel yang telah dipasang sisiran. gel dan cetakannya ditempatkan dalam chamber elektroforesis yang berisi $300 \mathrm{ml} \mathrm{TBE}$ buffer. Hasil PCR serbanyak $5 \mu \mathrm{l}$ dimasukkan dalam sumuran gel dan di elektroforesis pada tegangan 100 volt selama 30 menit. Kemudian gel divisualisasi dengan menggunakan UV transiluminator (Bio-rad) dan difoto dengan DSLR D1100 syngene genetic tool.

Digesti mtDNA dengan enzim restriksi

Digesti mtDNA dilakukan

menggunakan enzim restriksi. Enzim retriksi yang digunakan adalah HindIII, EcoRI, HhaI dan MspI. Tahapannya adalah mencampur $6 \mu \mathrm{l}$ $\mathrm{dH}_{2} \mathrm{O} ; 3 \mu \mathrm{l}$ DNA hasil amplifikasi PCR, buffer enzim $1 \mu$, enzim restriksi $1 \mu$ l sehingga total larutan $10 \mu \mathrm{l}$ dalam tabung PCR steril dan dilakukan on ice karena enzim sangat sensitif terhadap suhu dan mudah rusak kemudian campuran dihomogenkan dan diinkubasi pada suhu $37{ }^{\circ} \mathrm{C}$ selama 1-4 jam, selanjutnya dilakukan elektroforesis untuk mengetahui hasil digesti enzim dan untuk pengamatan jumlah dan ukuran fragmen Retriksi.

Siapkan tabung propilen $50 \mathrm{ml}$. Masukkan $4617 \quad \mu 1$ akuades, $2833 \mu 1$ poliakrilamid $30 \%, 850 \mu$ TBE buffer 10x, 195 $\mu 1$ APS dan $5 \mu$ TEMED ke dalam tabung propilen. Masukkan larutan ke dalam plate sampai penuh dan pasang sisiran pada plate. Plate berisi gel dimasukkan ke dalam chamber elektroforesis dan masukkan sebanyak $350 \mathrm{ml}$ TBE buffer 1x ke dalam chamber elektroforesis. Pada sumur pertama sebanyak $2 \mu$ l Marker DNA ladder. Sumur ke dua dan seterusnya dimasukkan sebanyak $10 \mu \mathrm{l}$ sampel hasil PCRRFLP dicampur dengan $2 \mu$ l loading dye. Runing dilakukan dengan tegangan 100 Volt sampai tracking dye berada $0.5 \mathrm{~cm}$ dari dasar gel. Gel dilepaskan dari plate dan dimasukkan ke dalam kotak plastik. Gel diberi larutan fiksatif ( $10 \%$ ethanol, $0.5 \%$ asam asetat glasial) dan difiksasi selama 20 menit. Kemudian gel diwarnai dengan $0.05 \%$ perak nitrat dan $0.05 \%$ formaldehid. Shaking selama 20 menit. Gel kemudian dicuci selama 1 menit dengan akuades. Gel diberi $\mathrm{NaOH} 2.5 \%$ dan $0.05 \%$ formaldehid lalu shaking sampai muncul pita.

\section{Analisa Data}

Analisa data dilakukan dengan metode deskriptif berdasarkan parameter keragaman haplotipe (h) dan jarak genetik antar populasi (Nei, 1987, dab Kumar 2000). Hubungan kekerabatan dan perbedaan jarak genetik yang nyata diilustrasikan dalam bentuk dendogram. Persamaan matematika keragaman haplotipe dan jarak genetik secara berturut turut sebagai berikut :

$$
\mathrm{h}=\frac{\mathrm{n}}{\mathrm{n}-1}\left(1-\sum \mathrm{X}_{\mathrm{i}}^{2}\right)
$$

$\mathrm{H}$ : keragaman haplotipe

$\mathrm{N}$ : jumlah sampel

$\mathrm{X}_{\mathrm{i}}$ : frekuensi haplotipe sampel ke-i

$$
\begin{gathered}
\mathrm{D}=-\ln \mathrm{I} \\
\mathrm{I}=\frac{\sum_{\mathrm{i}=1}^{\mathrm{m}}\left(\mathrm{p}_{\mathrm{ix}} \times \mathrm{p}_{\mathrm{iy}}\right)}{\sqrt{\left(\sum_{\mathrm{i}=1}^{\mathrm{m}} \mathrm{p}_{\mathrm{ix}}{ }^{2}\right)\left(\sum_{\mathrm{i}=1}^{\mathrm{m}} \mathrm{p}_{\mathrm{iy}}{ }^{2}\right)}} \\
\mathrm{P}_{\mathrm{ix}}: \text { frekuensi alel ke-i dari populasi X } \\
\mathrm{P}_{\mathrm{iy}}: \text { frekuensi alel ke-i dari populasi Y } \\
\mathrm{D}: \text { jarak genetik }
\end{gathered}
$$


Rekapitulasi identifikasi genotype (tipe restriksi) mtDNA teramplifikasi hasil digesti dengan dua enzim (Hha1 dan Msp1) disajikan dalam Tabel 2.

Hasil pemotongan yang menunjukkan ukuran panjang fragmen berbeda akan memberikan tipe pemotongan (haplotipe) yang berbeda pula. Tipe pemotongan yang berbeda pada setiap individu dalam suatu populasi maupun antara populasi dapat disebabkan oleh terjadinya pergantian, penambahan atau hilangnya basa tertentu pada urutan basa DLoop mtDNAnya. Sehingga Enzim tertentu tidak memotong pada situs yang sama. Hal ini mengakibatkan terjadinya pergeseran situs pemotongan. Dengan demikian dapat dikatakan bahwa terdapat perbedaan urutan pasangan basa pada individu yang mempunyai tipe pemotongan basa yang berbeda. Hal ini mengakibatkan adanya keragaman genetik di dalam populasi dan antara populasi.

Keragaman Genetik

Hasil pemotongan produk PCR dengan menggunakan 2 enzim restriksi menghasilkan lima haplotipe mt DNA D-Loop region. Tipe composite haplotipe yang diperoleh disajikan dalam Tabel 3. Setiap enzim memiliki tipe restriksi (tipe pemotongan) yang berbeda.

\section{Hasil dan Pembahasan}

Hasil Amplifikasi daerah cyt b mtDNA pada Sidat ( Anguila bicolor ) menggunakan primer Cytochrome b (Cyt b-1) forward : 5'TGCTACGATGCCCTAGTGG - 3' dan $C y t b$ 2: 5'-CTAGTCAACCTACT - AATGGG - 3' menghasilkan fragmen DNA berukuran sekitar 1039 bp (base pairs) pada semua sampel lokasi yaitu Medan, Manado, Cilacap dan Tulungagung. (Gambar.1)

Dari empat enzyme yang digunakan untuk memotong templste mt-DNA tersebut (HindIII, EcoRI, HhaI dan MspI), hanya 2 enzym yang mempunyai sisi pemotongan yaitu HhaI dan MspI. Pemotongan fragmen mt-DNA dengan menggunakan enzyme HhaI menghasilkan dua jenis pola restriksi sedangkan enzyme MspI menghasilkan tiga tipe pola restriksi. (Gambar 2)

Panjang fragmen mt-DNA untuk masingmasing enzim restriksi dapat dilihat pada table 1. Dari table terlihat bahwa Digesti fragmen mtDNA teramplifikasi dengan enzim restriksi Hha 1 menghasilkan dua tipe yaitu A (523, 516 pb), dan B (147, $892 \mathrm{pb})$.

Sedangkan digesti enzim restriksi $M s p 1$ menghasilkan tiga tipe yaitu A $(203,325,511$ pb), B (203, 415, $415 \mathrm{pb})$ dan C (511, $528 \mathrm{pb})$. Analisis composite haplotipe menghasilkan tiga composite haplotipe pada seluruh kelompok sampel, nilai keragaman haplotipe bervariasi antara (0.0) (Sampel Manado, Medan Cilacap) sampai 0.2 (sampel Tulungagung) ( Tabel 3). Jumlah terendah yang diamati adalah pada kelompok sampel Manado, Medan Cilacap ( satu composite haplotipe). Sedangkan jumlah yang tertinggi terdapat pada kelompok sampel Tulungagung ( tiga composite haplotipe)

Jarak genetik antar populasi (D) dan dendogram hubungan kekerabatan antar populasi (filogeni) pada empat populasi sidat menurut metode UPMGA dengan menggunakan program software TFPGA disajikan dalam Tabel 4

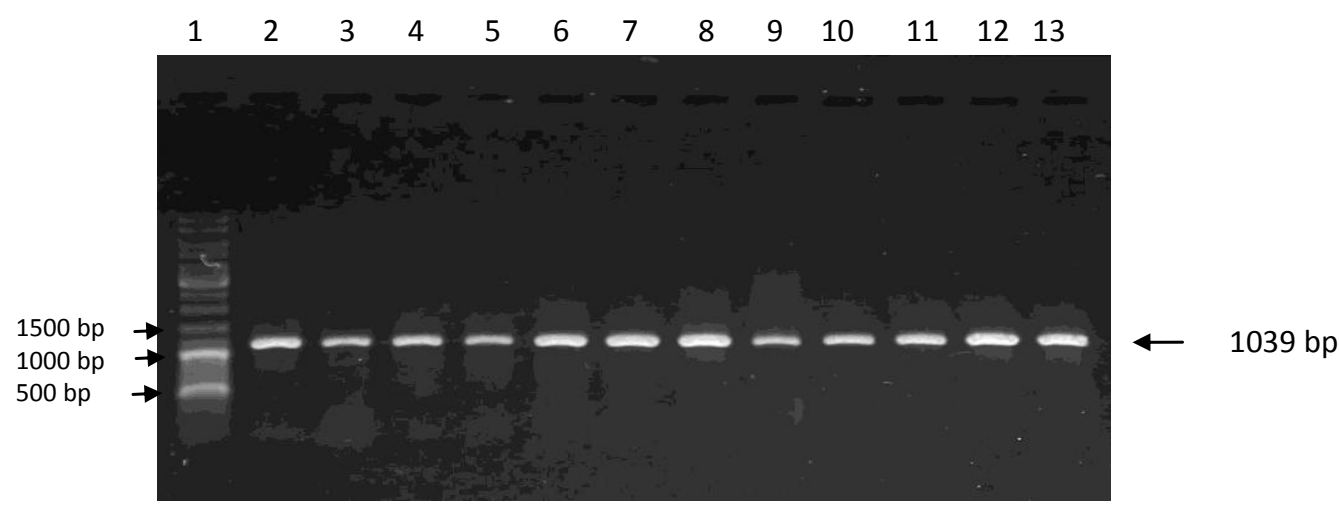

Gambar 1. Fragmen tunggal mtDNA pada Sidat (A. bicolor) yang diamplifikasi dengan primer $c y t b$ Keterangan : 1 : Marker 10kb, $2-4$ : sampel Cilacap, 5-7: sampel Medan, $8-10:$ sampel Manado, 11 - 13 : sampel Tulungagung, bp : pasangan basa 
$\begin{array}{lllllllllllll}1 & 2 & 3 & 4 & 5 & 6 & 7 & 8 & 9 & 10 & 11 & 12 & 13\end{array}$

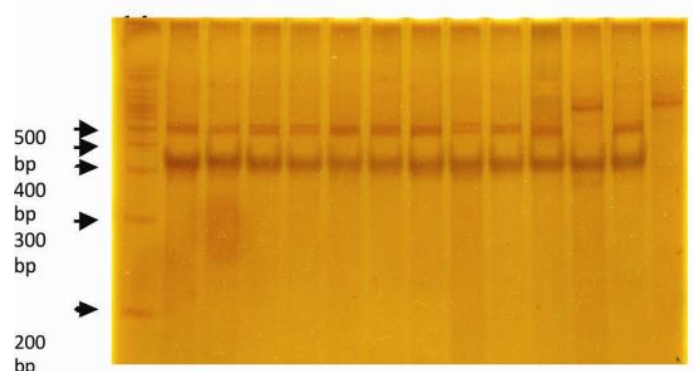

$\begin{array}{llllllllllllll}1 & 2 & 3 & 4 & 5 & 6 & 7 & 8 & 9 & 10 & 11 & 12 & 13 & 14\end{array}$

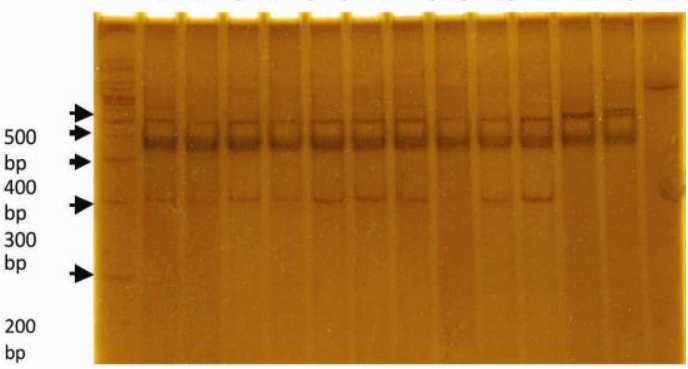

Gambar 2. Hasil pemotongan fragmen mr-DNA dengan menggunakan enzyme HhaI dan MspI pada sidat (Anguila bicolor)

Tabel 1. Tipe fragmen restriksi mtDNA daerah $c y t b$ dengan dua enzim restriksi Hha1 dan Msp1

\begin{tabular}{|c|c|c|c|c|c|}
\hline \multirow{3}{*}{$\begin{array}{c}\text { Panjang fragmen } \\
\text { (bp) }\end{array}$} & \multicolumn{5}{|c|}{ Enzim } \\
\hline & \multicolumn{2}{|c|}{ Hha I } & \multicolumn{3}{|c|}{$M s p$ I } \\
\hline & A & B & A & B & $\mathrm{C}$ \\
\hline 892 & & & & & \\
\hline 528 & & & & & \\
\hline 523 & & & & & \\
\hline 516 & & & & & \\
\hline 511 & & & & & \\
\hline 415 & & & & & \\
\hline 325 & & & & & \\
\hline 203 & & & & & \\
\hline 147 & & & & & \\
\hline Total & 2 & 2 & 3 & 3 & 2 \\
\hline
\end{tabular}

Tabel 2. Distribusi genotype (tipe restriksi) pada empat populasi sidat

\begin{tabular}{|c|c|c|c|c|c|}
\hline \multirow{2}{*}{ Enzim } & $\begin{array}{c}\text { Type } \\
\text { restriksi }\end{array}$ & Medan & Manado & Cilacap & Tulungagung \\
\hline \multirow{2}{*}{ Hha 1} & A & 3 & 3 & 3 & 1 \\
& B & - & - & - & 2 \\
\hline \multirow{2}{*}{ Msp 1} & A & 3 & 3 & 3 & 1 \\
& B & - & - & - & 1 \\
& C & - & - & - & 1 \\
\hline
\end{tabular}

Tabel 3. Distribusi frekuensi dan komposit haplotipe pada empat populasi sidat (Anguila bicolor)

\begin{tabular}{|c|c|c|c|c|c|c|}
\hline No & $\begin{array}{c}\text { Composite } \\
\text { haplotipe }\end{array}$ & Total & Medan & Manado & Cilacap & Tulungagung \\
\hline 1 & AA & 10 & 0.3 & 0.3 & 0.3 & 0.1 \\
2 & BB & 1 & - & - & - & 0.1 \\
3 & AC & 1 & - & - & - & 0.1 \\
\hline \multicolumn{2}{|r|}{ Jumlah sampel } & 12 & 3 & 3 & 3 & 3 \\
\hline \multicolumn{2}{|r|}{ Jumlah haplotipe } & 5 & 1 & 1 & 1 & 3 \\
\hline \multicolumn{2}{|r|}{ Keragaman haplotipe } & & 0.0 & 0.0 & 0.0 & 0.2 \\
\hline
\end{tabular}




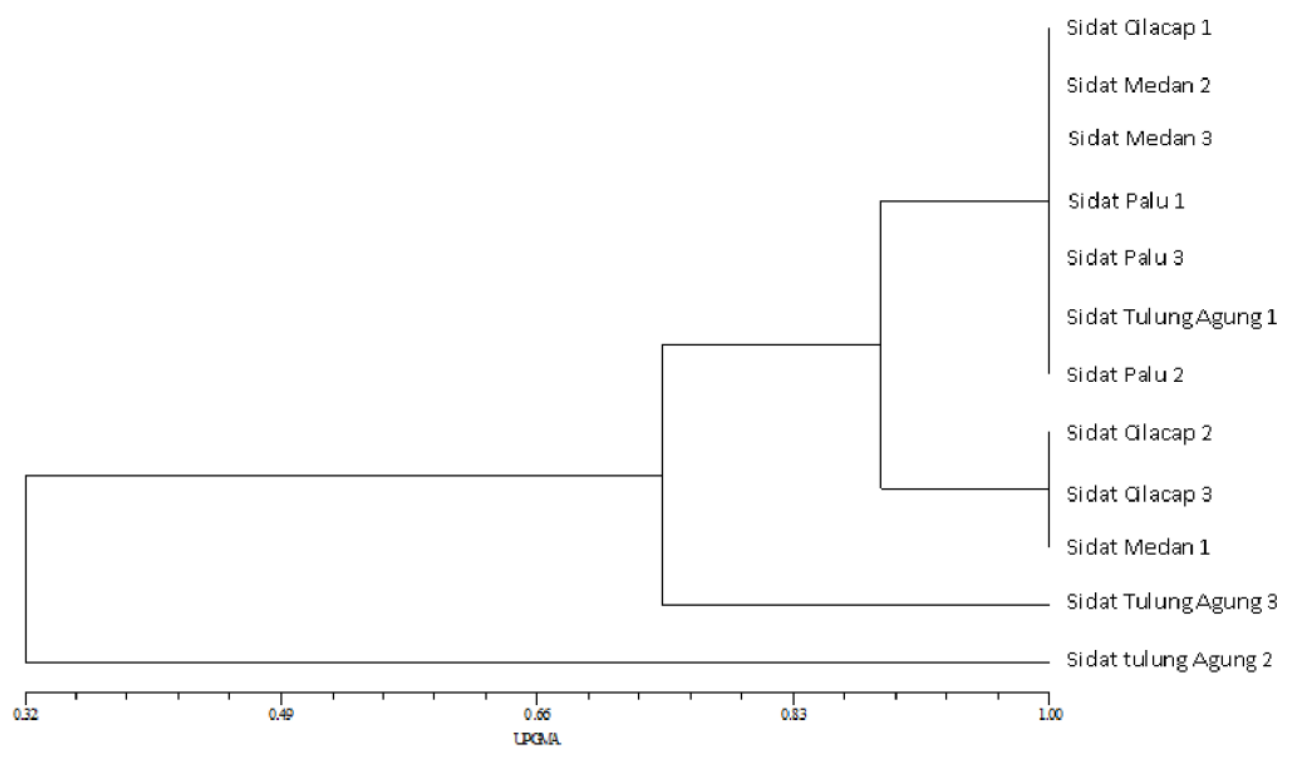

Gambar 3. Jarak genetik antar populasi

Jarak genetik antar populasi (D) dan dendogram hubungan kekerabatan antar populasi (filogeni) pada empat populasi sidat menurut metode UPMGA dengan menggunakan program software TFPGA disajikan dalam Tabel 4.

Hasil perhitungan jarak genetik menunjukkan jarak terkecil (terdekat) antara populasi Medan, Manado dan Cilacap yaitu sebesar 0.0000, sedangkan jarak genetik terbesar (terjauh) adalah populasi Tulungagung yaitu 0.0017 .

Berdasarkan dendogram kekerabatan empat populasi sidat (Anguila bicolor) menunjukkan bahwa nilai similaritas dari sampel sebagai berikut sidat cilacap 1, Medan 2, Medan 3, Manado 1, Manado 3, tulung agung 1 dan Manado 2 mempunyai nilai similaritas $100 \%$. Sidat cilacap 2, sidat cilacap 3 dan medan 1 mempunyai nilai similaritas $100 \%$.

Antara kelompok sidat Cilacap 1, Medan 2, Medan 3, Manado 1, Manado 3, Tulungagung 1 dan Manado 2 dan kelompok Sidat Cilacap 2, sidat Cilacap 3 dan Medan 1 mempunyai nilai similaritas sebesar $88.9 \%$. Sidat Tulungagung 3 terhadap kelompok sidat Cilacap 1, Medan 2, Medan 3, Manado 1, Manado 3, Tulungagung 1 dan Manado 2 dan kelompok Sidat Cilacap 2, sidat Cilacap 3 dan Medan 1 mempunyai nilai similaritas sebesar $74.4 \%$.

Sidat Tulungagung 2 terhadap Sidat Tulungagung 3, kelompok sidat Cilacap 1, Medan 2, Medan 3, Manado 1, Manado 3, Tulungagung 1 dan Manado 2 serta kelompok
Sidat Cilacap 2, sidat Cilacap 3 dan Medan 1 mempunyai nilai similaritas sebesar $32.2 \%$.

Tinggi rendahnya keragaman haplotipe genetik dapat diindikasikan dari jumlah maupun keragaman haplotipe (h) dan nukleotida. Hasil yang diperoleh dalam penelitian ini terindikasi tiga tipe composite haplotipe. Jumlah haplotipe ikan sidat yang dimiliki oleh masing masing sampel untuk sampel dari Manado, Medan dan Cilacap memiliki satu composit haplotipe yang sama. Distribusi composite haplotipe menunjukkan ciri khas ikan sidat pada masingmasing lokasi. Secara keseluruhan keragaman haplotipe wilayah Medan, Manado dan Cilacap adalah seragam (0.0), sedangkan sampel ikan sidat dati Tulungagung mempunyai nilai keragaman haplotipe (0.2).

Keragaman genetik antar populasi dapat dicirikan dari jarak genetik dalam klasifikasi atau pengelompokan ikan menggambarkan perbedaan nilai suatu cirri antara kelompok ikan yang dibandingkan. Semakin kecil nilai jarak genetik, semakin kecil pula keragamann antar populasi tersebut demikian pula sebaliknya.

Analisis dendogram berdasarkan UPGMA menunjukkan ada strukturisasi genetik sebagai gambaran pemisahan kelompok menjadi dua unit populasi, yaitu kelompok pertama yang terdiri dari sampel sidat dari Manado, Medan dan Cilacap dan kelompok II sampel sidat dari Tulungagung. Jarak genetik dan pola migrasinya diperkirkan mempengaruhi pemisahan kelompok sidat. Secara berturut 
turut nilai jarak genetik kedua populasi tersebut adalah 0.0000 dan 0.0017

Ilustrasi dendogram memberikan informasi kekerabatan dari keempat lokasi sampel pengambilan. Pola kekerabatan suatu ikan terjadi karena adanya penyebaran dan proses migrasi (ruaya). Adanya pemisahan populasi ikan sidat pada keempat lokasi pengambilan sampel diperkirakan terkait dengan faktor oseanografi dan geografis.

Sidat muda hidup selama beberapa tahun di sungai-sungai untuk melengkapi siklus reproduksinya. Ikan sidat mampu mencapai jarak perjalanan ruaya hingga 4000 mil. Selama melakukan ruaya pemijahan, induk sidat mengalami percepatan pematangan gonad dari tekanan hidrostatik air laut. Proses pemijahan berlangsung pada kedalaman $400 \mathrm{~m}$, sehingga pengaruh hidrostatis permukaan air lebih kecil dibandingkan dengan kondisi hidrostatis perairan lapisan dalam dan pengaruh lebih besar terjadi pada fase disporsal dan larva yang bersifat planktonik. Letak geografis yang relatif dekat mengakibatkan ketiga sampel dari lokasi berada dalam satu kelompok ( $\mathrm{D}=0.000)$.

Tingginya nilai keragaman haplotipe di Tulungagung ini disebabkan oleh kondisi perairan pantai di Tulungagung yang mempunyai tingkat produktifitas kesuburan yang tinggi, sehingga sidat dari Tulungagung secara genetik mempunyai sifat yang lebih unggul. Terkait dengan kondisi lingkungan perairan yang berbeda dari pengambilan sampel diduga memberi pengaruh terhadap munculnya keragaman genetik populasi sidat. Seperti pada sidat dari Tulungagung yang mempunyai nilai keragaman haplotipe yang tinggi (0.2) Hal ini terkait dengan kemampuan individu menyediakan ragam genetik alam mekanisme evolusi sehingga bertahan hidup dan bereproduksi. Koen et al (1976) menyatakan bahwa perbedaan genetik dapat terjadi karena letak geografis, perbedaan salinitas dan suhu. Perubahan keragaman alel yang mempengaruhi keragaman genetik juga disebabkan oleh migrasi, seleksi dan genetic drift (Frankham et al 2002).

Berdasarkan tipe haplotipe sampel dari Medan dan Cilacap AA juga ditemukan pada sampel dari Tulungagung, hal ini menunjukkan kedekatan secara geografis dan pertukaran populasi sidat terkait buidaya yang dilakukan. Nilai keragaman haplotipe yang rendah dari rata-rata sidat di tiga lokasi sesuai dengan pendapat Sugama dan Hutapea bahwa populasi dengan laju migrasi yang sempit atau jarak yang pendek mempunyai heterosigositas yang rendah bila dibandingkan dengan populasi yang mempunyai migrasi yang luas dan bersifat terbuka. Terjadinya pertukaran gen dalam melakukan perkawinan dapat mengakibatkan perkawinan sekerabat yang bila terjadi secara berulang-ulang dapat mengakibatkan rendahnya variasi genetik / munculnya peluang homosigositas akan lebih tinggi.

\section{Kesimpulan}

Keragaman haplotipe (genetik) dari empat populasi sampel ikan sidat bervariasi antara $0.0-0.2$ Keragaman haplotipe terendah 0.0 terdapat pada kelompok sampel Manado, Medan dan Cilacap dan yang tertinggi 0.2 terdapat pada kelompok sampel Tulungagung.

Jarak genetik antar kelompok sampel berkisar antara $0.000-0.0017$. Jarak genetik terdekat adalah antara kelompok sampel Manado, Medan dan Cilacap sedangkan jarak genetik terjauh sampel Tulungagung dengan nilai jarak genetik 0.0017 .

Dendogram yang dibentuk berdasarkan jarak genetik menunjukkan bahwa kelompok sidat yang diamati dapat dibagi menjadi dua kelompok populasi yaitu kelompok pertama terdiri dari ikan sidat yang berasal dari kelompok sampel Manado, Medan, Cilacap sedangkan kelompok kedua berasal dari sampel Tulungagung.

\section{Daftar Pustaka}

Aoyama, J., H. Sugeha, dan K. Tsukamoto. 2006. Downstream Migration of Tropical Anguillid Silver Eels. Prosiding Seminar Nasional Limnologi 2006

Avis, J.C. Lansman and R.O. Shade. 1979. The use Endonuclease to Mesure Mitochondria DNA Sequense Relatedness in Natural Populayions. I. Population Structure and Evolution in Genus Peromyscus. Genetic 92:279295

Botstein., D.R., R.L White, M.Skolnick, and R.W. Davis. 1980. Construction of a Genetic Linkage Map in man Using Restriction Fragment Length Polymorphism, Am.J.Hum.Gen. 32:31314-331

Brown, T. A. 1991. Pengantar Kloning Gen. Yogyakarta: Yayasan Essentia Medica

Desjardin, P. and R. Moris. 1990. Sequence and gene organization of chicken mitochondria genom. A novel gene order in higjer vertebrate.J.Mol. Biol.212.599-624.

Duryadi, 1994. Peran DNA Mitokondria (mt DNA) dalam studi keragaman genetic 
dan biologi populasi pada hewan. Hayati, Jurnal Biologi FMIPA IPB. 1(1):1-4

Effendie, M.I. 1997. Biologi Perikanan, Yayasan Pustaka Nusatama, Yogyakarta, $163 \mathrm{p}$

Hardys, H., M. Balick, and B. Schiewater, 1992. Application of Random Amplified Polymorphic DNA (RAPD) in Mol Ecol. 1: $56-63$.

Setiawan I.E, Rovara, O dan M.H Amarullah. 2007. Mengenal Sumberdaya Ikan Sidat. BPPT-HSF, Jakarta. Program Pasca Sarjana Institut Pertanian Bogor

Kocher T.D., Lee W.J., Sobolewska H., Penman D. \& McAndrew B.1989. A Genetic Linkage Map Of A Cichlid Fish, The Tilapia (Oreochromis niloticus). Genetics 148.

Maniatis, T. Sambrook, J. and Fritsch, E.F. 1989. Molecular Cloning (2th ed.). Harbor:Cold Spring Harbor Laboratory Press. New York.

Moria, S.B. Haryanti. Permana, I. G. N and Sugama, K.2001. Keragaman dan Kekerabatan Tiga Spesies Kerapu Epinephelus spp. Dengan Metode Restriction Fragment Length Polymorphism (RFLP) mtDNA. Teknologi Budidaya Laut dan Pengembangan Sea Farming di Indonesia. Jakarta:Departemen Kelautan dan Perikanan. Hal.285-292

Nelson, J.S. 1994. Fishes of The World, $3^{\text {rd }}$ editions. John Wiley and Sons, Inc., New York, 600pp

Ovendem J (2000). Development and Restriction Enzyme Markers for Red Lutjanus malabaricus) Stock Descrimination Using Genetic Variation in Mitochondrial DNA. Molecular Fisheries Laboratory Southern Fisheries Centre. Produced for CSIRO Marine Laboratories as Part of The ACIAR Indonesia Snapper Project

Perez-Enriquez, R., Takagi, M. and Taniguchi, N. (2007). Genetic Variability And Pedigree Tracing Of A HatcheryReared Stock Of Redsea Bream (Pagrus Major) Used For Stock Enhancement, Based On Microsatellite DNA markers. Aquaculture 173, 413423.

Primack, R. B. Supriatna, J. Indrawan, M. \& Kramandibrata,P. 1998. Essentials of
Conservation Biology. Sinauer Asssociate, Sunderland, Massachusetts. Saputra, D. 2009. Gambaran (RFLP) Gen Sitokrom b DNA Mitokondria dari Sembilan Spesies Ikan Air Tawar. Skripsi Fakultas Kedokteran Hewan, Institut Pertanian Bogor.Setiawan I.E, Rovara, O dan M.H Amarullah. 2007. Mengenal Sumberdaya Ikan Sidat. BPPT-HSF, Jakarta. Program Pasca Sarjana Institut Pertanian Bogor.

Sartika, Tike, 2000. Studi Keragaman Fenotip dan Genetik Ayam Kampung pada populasi dasar seleksi. Thesis. Program Pasca Sarjana Institut Pertanian Bogor. Bogor

Teng, H.Y, Y.S. Lin, dan T.S. Tzeng. 2009. A New Anguilla Species and a Reanalysis of the Phylogeny of Freshwater Eels. Department of Life Science, National Tsing Hua University, Hsinchu 300, Taiwan. J. 48(6): 808-822

Tesch, F.W. 1977. The eel biology and management of anguila eels. Chapman and Hall. London 434 p. Snapper (Lutjanus erythropterus and genus anguila. University of Tokyo. J. coastal marine Sci. 32 (3)

Watanabe, S, J. Aoyama, K. Tsukamoto. 2008. The Use of Morphological and molecular genetic variation in the genus anguila. University of Tokyo. J. coastal marine Sci. 32 (3)

Warwick, E.J., H.J.Astuti,M.J. and W. Hardjo Subroto, 1987. Pemuliaan. Ternak. Gajah Mada University Press. Jogjakarta 